\title{
Effect of Domestic Processing Methods on Dry Matter, Total Sugar, Phenolics and Mineral Composition in Different Developmental Stages of Parkia roxburghii G. (Don.) Pods
}

\author{
Jekendra Singh SALAM ${ }^{1 *}$, Priyadarshini SALAM ${ }^{2}$, Kumar Singh \\ POTSHANGBAM ${ }^{3}$, Biman Kumar DUTTA ${ }^{4}$ \\ ${ }^{1}$ Central Agricultural University, College of Agriculture, Dept. of Soil Science and Agricultural Chemistry, \\ Iroisemba, Imphal-795 001, India; jekendrasalam@rediffmail.com ("corresponding author) \\ ${ }^{2}$ OUAT, College of Agriculture, Department of Horticulture, Bhubaneswar, Orissa, India; priacrotchet19@gmail.com \\ ${ }^{3}$ Manipur University, Centre of Advanced Study in Life Sciences, Canchipur, Imphal, India; potshangbam031@gmail.com \\ ${ }^{4}$ Assam University, Dept. of Ecology and Environment, Silchar, Assam, India; bimandutta@rediffmail.com
}

\begin{abstract}
Parkia roxburghii is considered delicious in the Northeastern part of India, especially in the state of Manipur. Though it is widely used, information about the biochemical composition and its changes, after processing, is hardly available. In the present experiment, effect of processing methods on dry matter, soluble sugar, phenolics and mineral composition in different developmental stages of $P$. roxburghii pods were studied. Total soluble sugar (TSS), total phenols (TP), and orthodihydric phenols (ODHP) were determined, also sodium $(\mathrm{Na})$, potassium $(\mathrm{K})$, sulphur $(\mathrm{S})$ and phosphorus $(\mathrm{P})$ were estimated. Calcium $(\mathrm{Ca})$, magnesium $(\mathrm{Mg})$, manganese $(\mathrm{Mn})$, zinc $(\mathrm{Zn})$, iron $(\mathrm{Fe})$, copper $(\mathrm{Cu})$ and cobalt $(\mathrm{Co})$ were analyzed in an atomic absorption spectrophotometer. Processing methods reduced dry matter, soluble sugar and phenolics in all the stages of the pod. TP and ODHP lost up to the extent of $72.78 \%$ in tender stage due to ordinary cooking, while higher loss of ODHP recorded in immature stage of the pod due to pressure cooking. $\mathrm{Ca}, \mathrm{Mg}, \mathrm{K}$ and $\mathrm{Zn}$ in different stages were found to be affected significantly by different methods of cooking, while no such changes were observed in case of $\mathrm{S}, \mathrm{P}, \mathrm{Fe}, \mathrm{Mn}$ and $\mathrm{Cu}$. The level of iron amongst the micro minerals is appreciably high recording up to $51.0 \mathrm{mg} / 100 \mathrm{~g}$ in the immature stage of the pod. As iron, zinc and manganese are antioxidant micronutrients, their higher presence in P. roxburghii might be of some nutritional importance.
\end{abstract}

Keywords: minerals, Parkia roxburghii, phenolics, processing methods, soluble sugar

\section{Introduction}

There are at least 3000 edible plant species known by man out of which, merely 300 crops contribute to more than $90 \%$ of the world's calorie intake, and only 120 crops are economically important on an international scale which implies that world's food security rests on a slender base of $4 \%$ of known edible plants (Cooper et al., 1996). Therefore, from the point of view of meeting the challenges of food security, it is necessary to widen the food base by establishing more and more new food crops.

Due to topography and climatic conditions the NorthEastern region of India is noted for its great diversity of edible plants. This is evidenced by the fact that about $40 \%$ of the total flora of the country is said to be represented in the north eastern part of India, which means an approximate number of 6000 to 7000 species. Out of these some of the plants are used as edible green vegetables, edible fruits and for other purposes. Many investigators feel that the nutritional value of the identified wild edible plants worked out, so that their contribution to human health in terms of nutrition can be recommended for the benefit of people at large scale (Barua et al., 2007; Kayang, 2007; Ramachandra, 2007). As the legumes are a member of the Leguminoseae family, P. roxburghii (common name: Parkia or tree bean; Local name: Yongchak) also shares some of the anti-nutritional substances, endemic to legumes (Salam et al., 2010). It is important to reduce these anti-nutrients to improve the biological utilization of the plant. In India, the most important/common domestic processing and cooking methods include soaking, hulling, germination, ordinary and pressure cooking. These methods may reduce the anti-nutrients in legumes. There are a number of reports dealing with such information in the case of popular legumes, whereas no information is available regarding $P$. roxburghit, which is considered nutritious in this part of the country, especially in the state of Manipur and its adjoining areas. This paper reports part of a series of system- 
atic investigations undertaken to determine the biochemical composition of this lesser known legume (Salam et al., 2009; 2010; Sharma et al., 1993).

\section{Materials and methods}

Different stages of $P$. roxburghii pods were collected from a plant grown at Iroisemba, near the Central Agricultural University campus, and classified them into 3 groups based on the mean thickness of the pod measured at the site of seeds as tender ( $6 \mathrm{~mm}$ and below), immature $(6.1$ to $10 \mathrm{~mm})$ and mature (more than $10 \mathrm{~mm})$. All the pods were scrapped to remove the outer green peel. The margin of the pods were neatly removed with the help of a knife and cut into $10 \mathrm{~cm}$ (approximate) pieces. They had been divided into three groups of equal weights. Out of which, two groups had been subjected to different methods of cooking following the method of Saroj and Neelam (1994), while the third group was kept as control. All the process/cooked pods were air dried and kept in the oven at $60 \pm 5^{\circ} \mathrm{C}$ for 48 hours. The loss in dry matter was found out by subtracting the weight from the control and reported in percentage. The moisture free samples were then ground using a Remi grinder and subsequently sieved ( $1 \mathrm{~mm})$. The powder samples were collected and kept for various analyses.

The ethanol extract evaporated to dryness and dissolved in a known volume of water, used for the determination of total soluble sugar, total phenols, and orthodihydric phenols as per the methods of Morris (1948), Bray and Thorpe (1954) and Mahadevan and Sridhar (1986).

Wet digestion method of Capar et al. (1978) was followed for the analysis of mineral elements. Sodium $(\mathrm{Na})$ and potassium $(\mathrm{K})$ were estimated in a systronics-105 flame photometer. Sulphur (S) and phosphorus (P) were estimated in a UV-VIS double beam spectrophotometer following the procedures described by Tandon (1993). Calcium (Ca), magnesium ( $\mathrm{Mg})$, manganese $(\mathrm{Mn})$, zinc $(\mathrm{Zn})$, iron $(\mathrm{Fe})$, copper $(\mathrm{Cu})$ and cobalt $(\mathrm{Co})$ were analyzed in a Parkin Elmer atomic absorption spectrophotometer, Analyst AA-200. Standard errors of mean differences (S. Ed \pm ) and critical differences were calculated as per standard statistical procedures.
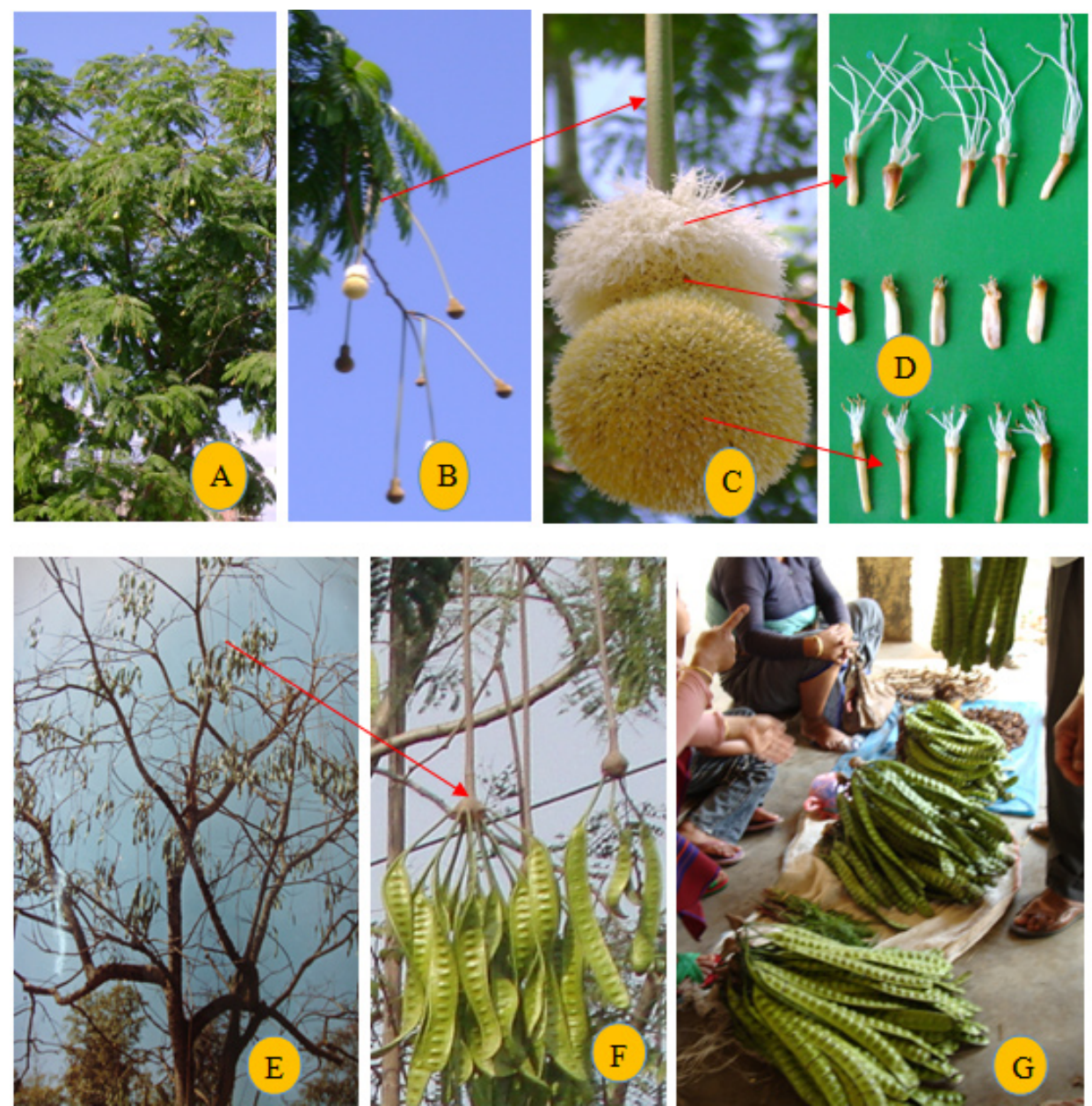

Fig. 1. Flowers and pods of $P$. roxburghii plant. (A) Flowering plant, (B) Inflorescence, (C) Flowers on a head/capitulum, (D) Different types of flowers (E) Plant with pods (F) Mature pods and (G) Pods being sold in the market 
52

\section{Results}

Changes in dry matter (DM) and total soluble sugar (TSS) content in pods: DM content increased from $19.1 \%$ in tender pod to $26.7 \%$ in mature pod. Processing methods affect DM content in all stages of the pod (Fig. 2A). Pressure cooking (PC) indicated higher loss of DM recording up to $27.7 \%$ in tender stage of the pod (Fig. 2B). Similarly, TSS content increases with the age of the pod by containing $6.92 \%$ in raw tender pod to $8.06 \%$ in the mature pod (Fig. 3A). However, the effect of processing methods was more pronounced in case of TSS recording

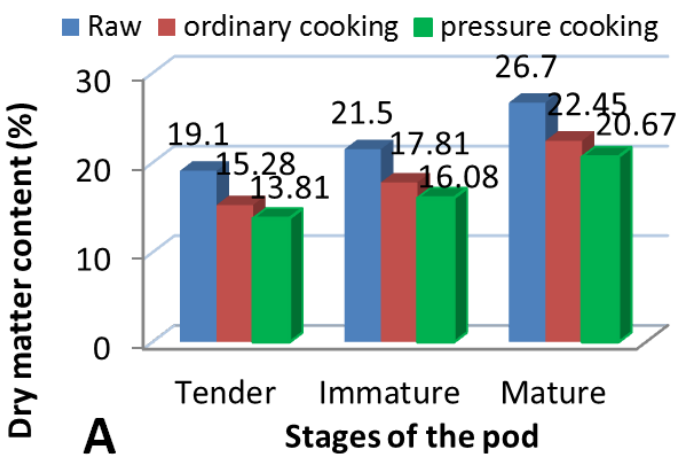

a loss of $78.36 \%$ of TSS by PC in the mature stage of the pod (Fig. 3B).

Changes in phenolics in the pods: Total phenol (TP) decreases with the age of the pod by containing 61.42 $\mathrm{mg} / \mathrm{g}$ in tender, $52.25 \mathrm{mg} / \mathrm{g}$ in immature and $37.70 \mathrm{mg} / \mathrm{g}$ in mature raw pods, which decreased to $16.72,17.82$ and $13.58(\mathrm{mg} / \mathrm{g}$ ) in ordinary cooking (OC) and to 20.10, 18.71 and $15.72(\mathrm{mg} / \mathrm{g})$ in PC (Fig. 4A). Different processing methods removed total phenols up to the extent of $72.78 \%, 65.89 \%$ and $63.98 \%$ of the original content in tender, immature and mature stages of the pod by OC and $67.27 \%, 64.19 \%$ and $58.30 \%$ by PC, respectively (Fig. 4B).

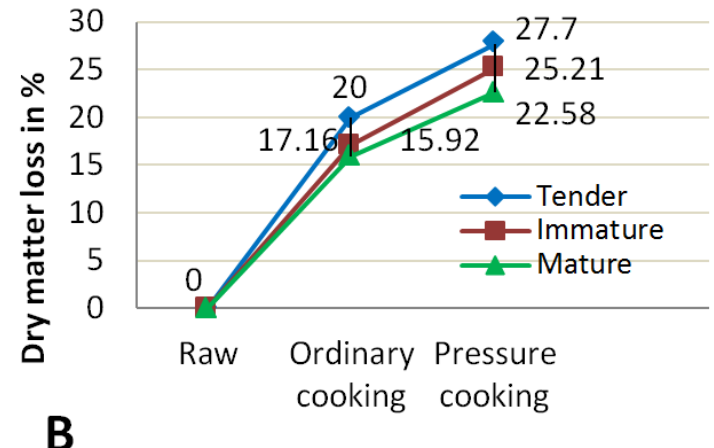

Fig. 2. Effect of different processing methods on dry matter content: (A) Bar graph showing changes in dry matter and (B) line graph showing degree of loss out of the total content in different stages of the P. roxburghii pods
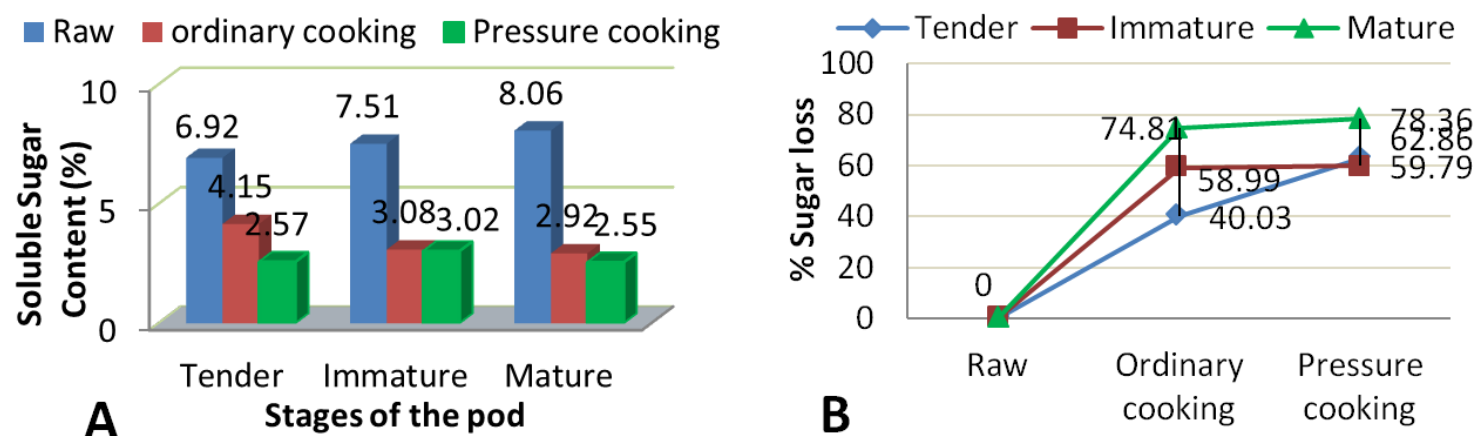

Fig. 3. Effect of different cooking methods on total soluble sugar (TSS) content in P. roxburghii: (A) Bar graph showing changes in TSS content and (B) line graph showing degree of loss out of the total content in different stages of the pod

naw (control) a Ordinary Cooking Dressure Cooking

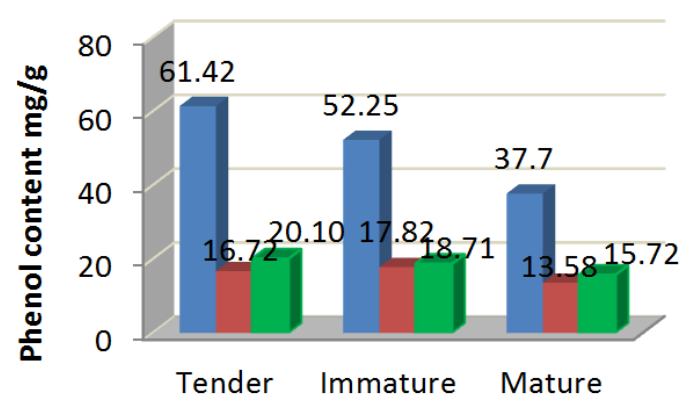

A

Stages of the pod

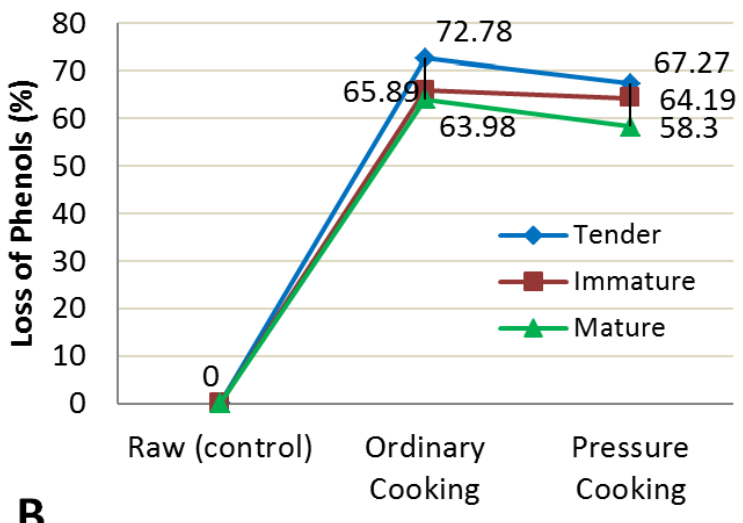

Fig. 4. Effect of different processing methods on total phenol (TP) content in P. roxburghii: (A) Bar graph showing changes in TP content and (B) line graph showing degree of loss out of the total content in different stages of the pod 
The same trend was also observed in orthodihydric phenols (ODHP). ODHP in the raw pod decreased with the pod maturation, which decreased to $0.63,0.54$ and 0.52 $\mathrm{mg} / \mathrm{g}$ in $\mathrm{OC}$ and to $0.74,0.35$ and $0.52 \mathrm{mg} / \mathrm{g}$ in PC (Fig. $5 \mathrm{~A})$. ODHP removed due to different processing methods was $81.14 \%, 76.21 \%$ and $51.85 \%$ by OC and $77.84 \%$, $84.58 \% \%$ and $51.85 \%$ by PC, respectively (Fig. $5 \mathrm{~B}$ ).

Changes in mineral content in the pods: Tab. 1 indicates changes in the major element composition in dif- ferent stages of the pod. Ca content in raw tender $(238$ $\mathrm{mg} / 100 \mathrm{~g})$, immature $(404.01 \mathrm{mg} / 100 \mathrm{~g})$ and mature $(398.53 \mathrm{mg} / 100 \mathrm{~g})$ pods decreased to $174.02,288.01$ and $250.01 \mathrm{mg} / 100 \mathrm{~g}$ due to OC, while it decreased to $177.92,328.52$ and $300.52 \mathrm{mg} / 100 \mathrm{~g}$ due to PC. $\mathrm{Mg}$ and $\mathrm{K}$ content $(226.20$ and $2760 \mathrm{mg} / 100 \mathrm{~g})$ in tender stage of the pod decreased to 156.20 and $2400(\mathrm{mg} / 100 \mathrm{~g})$ in ordinary cooking and to 150.0 and $2440(\mathrm{mg} / 100 \mathrm{~g})$ in pressure cooking. Similar trends were observed in immature

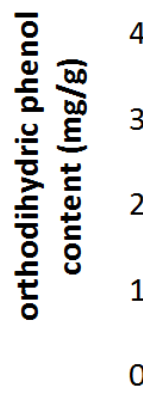

A

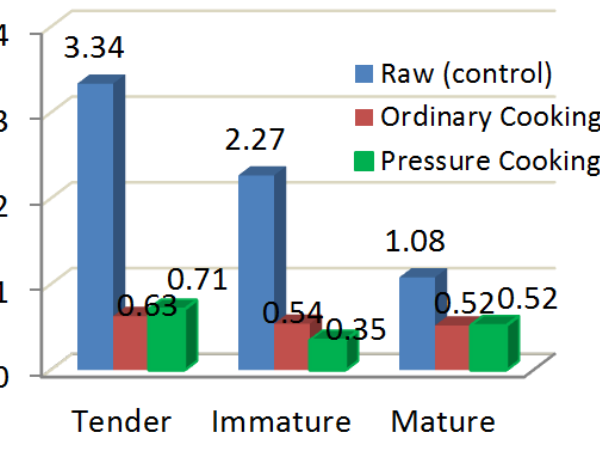

Stages of the pod

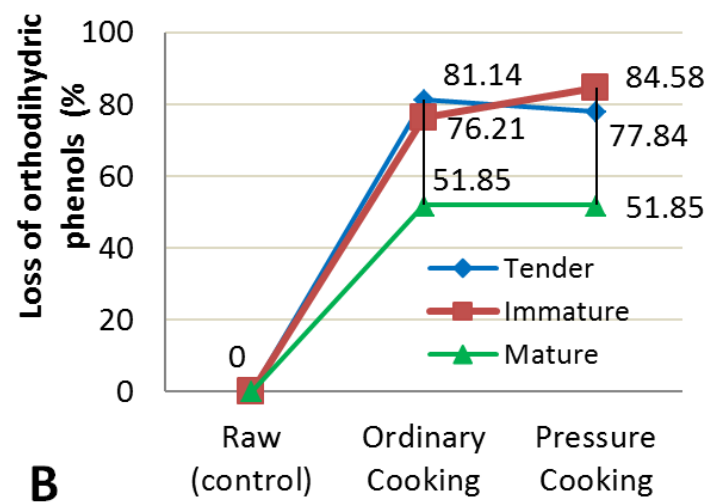

Fig. 5. Effect of different cooking methods on orthodihydric phenol ODHP) content in P. roxburghii: (A) Bar graph showing changes in ODHP content and (B) line graph showing degree of loss out of the total content in different stages of the pod

Tab. 1. Effect of cooking methods on major element content in different developmental stages of P. roxburghii pod (mg/100 g)

\begin{tabular}{|c|c|c|c|c|c|c|c|c|c|c|}
\hline \multirow{2}{*}{$\begin{array}{c}\text { Major } \\
\text { Element }\end{array}$} & \multirow{2}{*}{\multicolumn{2}{|c|}{ Cooking methods }} & \multicolumn{6}{|c|}{ Stages } & \multirow{2}{*}{\multicolumn{2}{|c|}{ Mean Stages }} \\
\hline & & & \multicolumn{2}{|c|}{ Tender } & \multicolumn{2}{|c|}{ Immature } & \multicolumn{2}{|c|}{ Mature } & & \\
\hline \multirow{4}{*}{$\mathrm{Ca}$} & \multicolumn{2}{|c|}{ Raw } & \multicolumn{2}{|c|}{$238.00^{\mathrm{a}}$} & \multicolumn{2}{|c|}{$404.01^{a}$} & \multicolumn{2}{|c|}{$398.53^{\mathrm{a}}$} & \multicolumn{2}{|c|}{346.85} \\
\hline & \multicolumn{2}{|c|}{ Ordinary Cooking } & \multicolumn{2}{|c|}{$174.02^{\mathrm{b}}$} & \multicolumn{2}{|c|}{$288.01^{\mathrm{b}}$} & \multicolumn{2}{|c|}{$250.01^{\mathrm{b}}$} & \multicolumn{2}{|c|}{237.35} \\
\hline & \multicolumn{2}{|c|}{ Pressure Cooking } & \multicolumn{2}{|c|}{$177.92^{\mathrm{b}}$} & \multicolumn{2}{|c|}{$328.52^{\mathrm{b}}$} & \multicolumn{2}{|c|}{$300.52^{c}$} & \multicolumn{2}{|c|}{268.99} \\
\hline & \multicolumn{2}{|c|}{ Mean (Methods) } & \multicolumn{2}{|c|}{196.65} & \multicolumn{2}{|c|}{340.18} & \multicolumn{2}{|c|}{316.35} & & \\
\hline \multirow{4}{*}{$\mathrm{Mg}$} & \multicolumn{2}{|c|}{ Raw } & \multicolumn{2}{|c|}{$226.20^{a}$} & & & & & & \\
\hline & Ordinar & poking & & & & & & & & \\
\hline & Pressur & oking & & & & & & & & \\
\hline & Mean ( & hods) & & & & & & & & \\
\hline & & & & & & & & & & \\
\hline$K$ & Ordinar & ooking & & & & & & & & \\
\hline $\mathbf{K}$ & Pressur & oking & & & & & & & & \\
\hline & Mean ( & hods) & & & & & & & & \\
\hline & & & & & & & & & & \\
\hline S & Ordinar & poking & & & & & & & & \\
\hline 3 & Pressur & oking & & & & & & & & \\
\hline & Mean ( & hods) & & & & & & & & \\
\hline & & & & & & & & & & \\
\hline P & Ordinar & poking & & & & & & & & \\
\hline$P$ & Pressur & oking & & & & & & & & \\
\hline & Mean ( & hods) & & & & & & & & \\
\hline & & & & & & & & & & \\
\hline & Methods & Stages & Methods & Stages & Methods & Stages & Methods & Stages & Method & Stages \\
\hline S.Ed \pm & 17.59 & 17.59 & 18.11 & 18.11 & 55.14 & 55.14 & 4.38 & 4.38 & 7.03 & 7.03 \\
\hline $\mathrm{CD} / .05$ & 48.83 & 48.83 & 50.26 & NS & 153.08 & NS & NS & NS & NS & NS \\
\hline $\mathrm{CD} /{ }_{01}$ & 80.98 & 80.98 & 83.36 & - & 253.88 & - & - & - & - & - \\
\hline
\end{tabular}

Note: NS=Non-significant; Different letters in a column indicate significance at $5 \%$ level 
54

and mature stages of the pod. $\mathrm{Ca}, \mathrm{Mg}$ and $\mathrm{K}$ in different stages were found to be affected significantly by different methods of cooking, while no such changes were observed in case of $S$ and P. Tab. 2 indicates the changes of minor elements in different stages of the pod. Cooking methods did not affect any significant changes in respect of Fe, Mn and $\mathrm{Cu}$, however, significant changes were observed in case of $\mathrm{Zn}$. $\mathrm{Zn}$ content in tender (10.05), immature(10.15) and mature $(6.18 \mathrm{mg} / 100 \mathrm{~g})$ raw pods decreased to 6.10 , 6.12 and $3.12 \mathrm{mg} / 100$ in ordinary cooking and to 7.50 , 7.13 and $6.0 \mathrm{mg} / 100 \mathrm{~g}$ in pressure cooking. The degree of minerals loss due to different processing methods is indi-
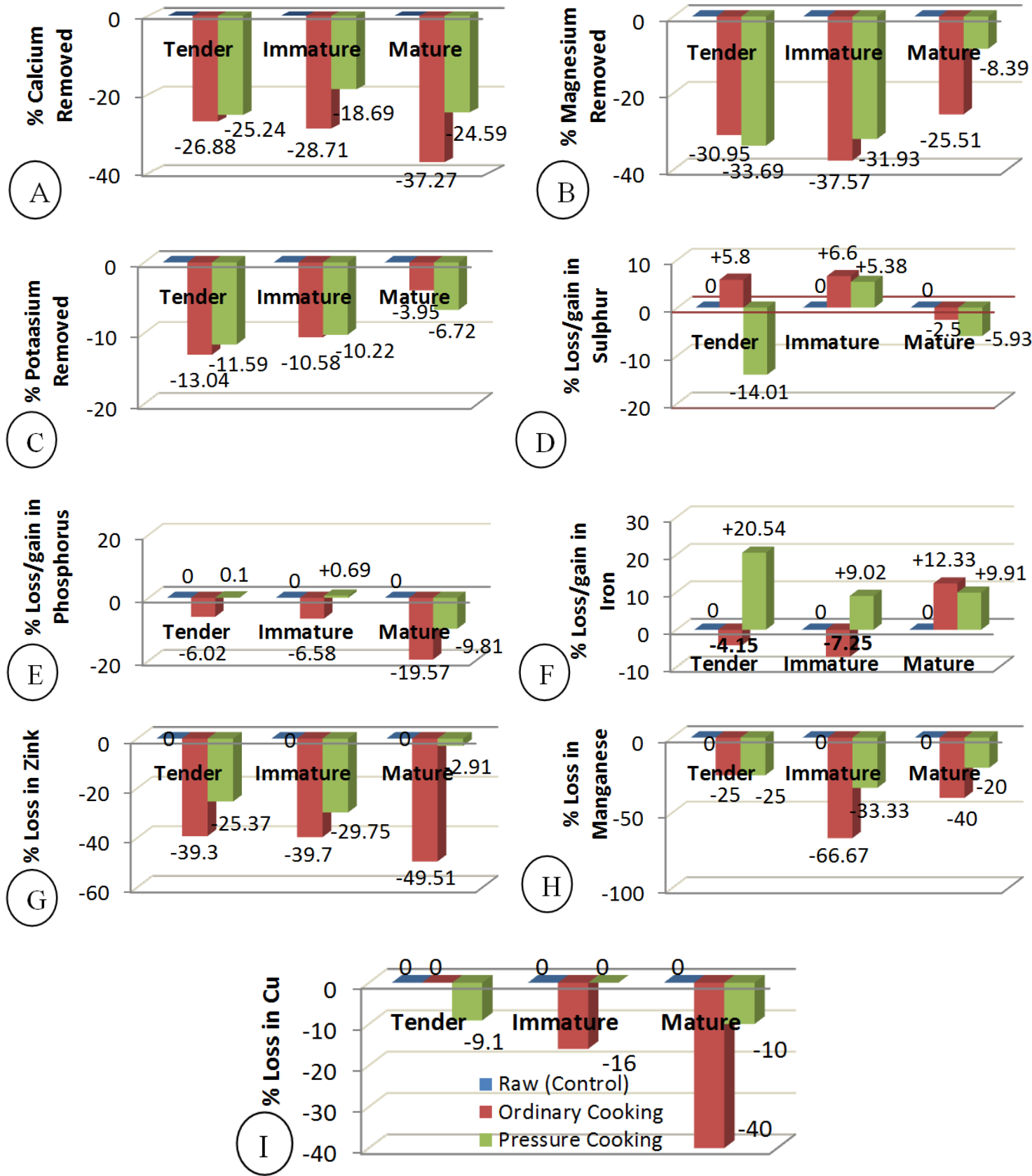

Fig. 6(A-I). Bar graph showing per cent loss/gain out of the respective total element content due to different processing methods in different stages of P. roxburghii pods.(A) Calcium, (B) Magnesium, (C) Potassium, (D) Sulphur, (E), Phosphorus, (F) Iron, (G) Zink, (H) Manganese and (I) Copper. (Legend:- Raw (control), $\cdot$ Ordinary cooking and Pressure cooking)

cated at Fig. 6(A-I). Percent removal of Ca was $26.88 \%$ to $37.27 \%$ by OC, while it was $25.51 \%$ to $37.57 \%$ in $\mathrm{Mg}$ and $3.95 \%$ to $13.04 \%$ in $\mathrm{K}$ (Fig. 6A-C). Processing methods seemed to be less effected on $\mathrm{S}, \mathrm{P}$ and Fe content of the pods (Fig. 6D-F). S and Fe content even increased due to processing methods recording a gain of $6.58 \%$ and $12.33 \%$ in $\mathrm{OC}$ and $5.38 \%$ and $20.54 \%$ in PC. However, the degree of loss was higher in case of $\mathrm{Zn}, \mathrm{Mn}$ and $\mathrm{Cu}$, recording up to $49.51 \%, 66.67 \%$ and $40 \%$ by OC and up to $29.75 \%$, $33.33 \%$ and $10 \%$ by PC, respectively, in different stages of the pod (Fig. 6G-I).

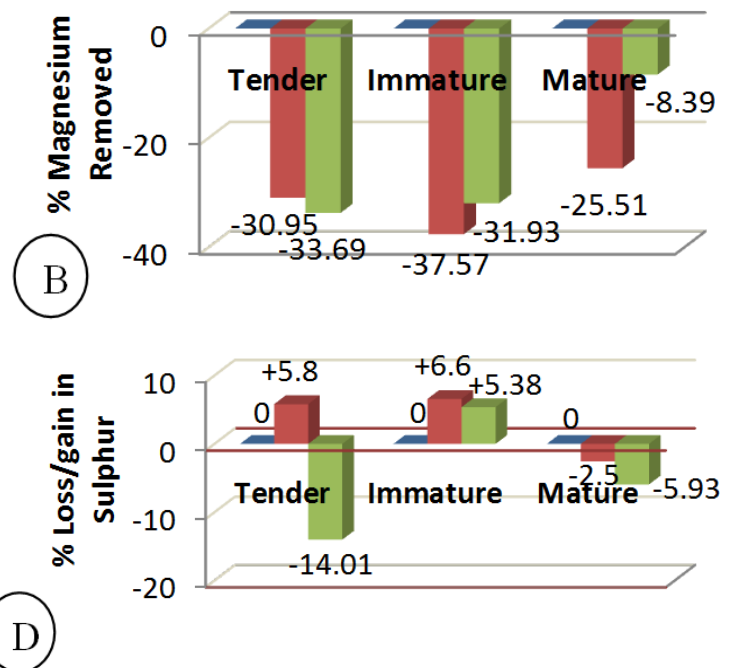


Tab. 2. Effect of cooking methods on minor element content in different developmental stages of P. roxburghii pod (mg/100 g)

\begin{tabular}{|c|c|c|c|c|c|c|c|c|c|c|}
\hline \multirow{2}{*}{$\begin{array}{l}\text { Major } \\
\text { Elements }\end{array}$} & \multirow{2}{*}{\multicolumn{2}{|c|}{ Cooking methods }} & \multicolumn{6}{|c|}{ Stages } & \multirow{2}{*}{\multicolumn{2}{|c|}{ Mean Stages }} \\
\hline & & & \multicolumn{2}{|c|}{ Tender } & \multicolumn{2}{|c|}{ Immature } & \multicolumn{2}{|c|}{ Mature } & & \\
\hline \multirow{4}{*}{$\mathrm{Fe}$} & \multicolumn{2}{|c|}{ Raw } & \multicolumn{2}{|c|}{48.2} & \multicolumn{2}{|c|}{51.0} & \multicolumn{2}{|c|}{45.4} & \multicolumn{2}{|c|}{48.20} \\
\hline & \multicolumn{2}{|c|}{ Ordinary Cooking } & \multicolumn{2}{|c|}{46.2} & \multicolumn{2}{|c|}{47.3} & \multicolumn{2}{|c|}{51.0} & \multicolumn{2}{|c|}{48.17} \\
\hline & \multicolumn{2}{|c|}{ Pressure Cooking } & \multicolumn{2}{|c|}{58.1} & \multicolumn{2}{|c|}{55.6} & \multicolumn{2}{|c|}{49.9} & \multicolumn{2}{|c|}{54.53} \\
\hline & \multicolumn{2}{|c|}{ Mean (Methods) } & \multicolumn{2}{|c|}{50.83} & \multicolumn{2}{|c|}{51.30} & \multicolumn{2}{|c|}{48.77} & & \\
\hline \multirow{4}{*}{$\mathrm{Zn}$} & \multicolumn{2}{|c|}{ Raw } & \multicolumn{2}{|c|}{$10.05^{a}$} & \multicolumn{2}{|c|}{$10.15^{a}$} & & & & \\
\hline & Ordinar & ooking & & & & & & & & \\
\hline & Pressure & oking & & & & & & & & \\
\hline & Mean $(1$ & hods) & & & & & & & & \\
\hline & & & & & & & & & & \\
\hline & Ordinar & ooking & & & & & & & & \\
\hline $\mathrm{Mn}$ & Pressure & oking & & & & & & & & \\
\hline & Mean $(1$ & hods) & & & & & & & & \\
\hline & & & & & & & & & & \\
\hline$C_{1}$ & Ordinary & ooking & & & & & & & & \\
\hline $\mathrm{Cu}$ & Pressure & oking & & & & & & & & \\
\hline & Mean $(1$ & hods) & & & & & & & & \\
\hline & & & & & & & & & & \\
\hline Co & Ordinar) & ooking & & & & & & & & \\
\hline & Pressure & oking & & & & & & & & \\
\hline & & & & & & & & & & \\
\hline & Methods & Stages & Methods & Stages & Methods & Stages & Methods & Stages & Methods & Stages \\
\hline S.Ed \pm & 2.96 & 2.96 & 0.63 & 0.63 & 1.09 & 1.09 & 0.49 & 0.49 & - & - \\
\hline $\mathrm{CD} /{ }_{05}$ & NS & NS & 1.75 & 1.75 & NS & NS & NS & NS & - & - \\
\hline $\mathrm{CD} /{ }_{01}$ & - & - & 2.90 & 2.90 & - & - & - & - & - & - \\
\hline
\end{tabular}

Note: ND=Not detected; Different letters in a column indicate significance at $5 \%$ level

\section{Discussion}

$\mathrm{DM}$ and TS increased with the advancement of the pod (Fig. 2A and 3A), while TP and ODHP decreased (Fig. 4A and 5A). Processing methods reduced DM, TSS, $\mathrm{TP}$ and ODHP content in all the stages, the degree of loss in DM, TP and ODHP being higher before the pod matured (Fig. 2B, 4B and 5B). This may be due to the reason that as the pod advances, more and more cell walls are lignified thereby inhibiting loss due to leaching. However, contrary to this, higher loss of TSS was recorded in the mature stage of the pod indicating accumulation of water soluble sugars when the pod matured (Fig. 3B). Out of the two processes, pressure cooking increased loss of dry matter, as well as soluble sugar, which may be due to the fact that boiling at higher pressure rendered complex substances broken down into simpler units, increasing loss due to leaching. Cooking as well as autoclaving brought about slight decrease in glucose, fructose and sucrose levels and increased oligosaccharide content of all the varieties of lima bean (Ologhobo and Fetuga, 1988). Processing methods also influenced total phenolics in selected dry beans (Boateng et al., 2008). Significant reductions in case of phenolics and phytic acids, due to different processing methods, were also reported (Sinha and Kawatra, 2003).
Among the elements tested, $\mathrm{Ca}$ and $\mathrm{Zn}$ were the only ones differed significantly in various stages of the pod (Tab. 1 and 2 ). $\mathrm{K}$ was found to be the most abundant mineral found in the pods, recording up to $2760 \mathrm{mg} / 100 \mathrm{~g}$ in the tender stage of the pod, which is followed by $\mathrm{Ca}(404.01$ $\mathrm{mg} / 100 \mathrm{~g}), \mathrm{Mg}(302.20 \mathrm{mg} / 100 \mathrm{~g})$ and P (211 mg/100 g), respectively (Tab. 1 ).

Among the micro elements, $\mathrm{Fe}(51 \mathrm{mg} / 100 \mathrm{~g})$ recorded to be the most abundant element, which is followed by $\mathrm{Zn}$ $(10.15 \mathrm{mg} / 100 \mathrm{~g}), \mathrm{Mn}(9 \mathrm{mg} / 100 \mathrm{~g})$ and $\mathrm{Cu}(6 \mathrm{mg} / 100$ g) (Tab. 2). This might be of nutritional importance, especially in the part of the world where anemia and iron deficiency is relatively rampant as in the case of $P$. thonningii (Jimoh and Oladiji, 2005). Iron, zinc and manganese are antioxidant micronutrients and their high presence in $P$. roxburghii could therefore boost the immune system (Talwar et al., 1989).Though, both cooking methods did not differ significantly, the degree of loss was often found to be higher in case of ordinary cooking (Fig. 6A-I). Similar findings were also reported by other researchers, which may be due to leaching of minerals on account of the enhanced permeability of the seed coat by the process of cooking (Kingsley, 1995; Meiners et al., 1976). However, $\mathrm{S}$ and $\mathrm{Fe}$ increased due to processing methods, recording a gain of $6.58 \%$ and $12.33 \%$ in OC and $5.38 \%$ and $20.54 \%$ in PC (Fig. 6D and F). These results were in agreement 
56

with the reports of Chitra et al. (1996), who studied the effect of processing on various pulses and reported to have little effects on calcium, magnesium and iron contents. The increased in concentration of these elements may be due to complex formation at high temperature as phytic acid was reported to form an insoluble phytin compound with these elements (Thimmaiah, 2006). Such observations were also reported by Kingsley (1995). Cobalt was not detected in $P$. roxburghii pods.

\section{Conclusion}

P. roxburghii was a good source of $\mathrm{Ca}, \mathrm{K}, \mathrm{P}, \mathrm{Fe}, \mathrm{Zn}, \mathrm{Mn}$ and $\mathrm{Cu}$. In spite of being a leguminous plant, which was generally prone to many anti-nutritionals and toxic factors, especially more, so in the case of non-conventional legumes, parkia contains less amounts of anti-nutrients (Salam et al., 2010). Due to its wide adaptability in different soils, in varied altitudes as well as due to its nutritious pods and prolong availability for use, $P$. roxburghii, if properly exploited may be a nutritious vegetable supplement for the human consumption at large.

\section{References}

Barua U, Hore DK, Sarma R (2007). Wild edible plants of Majuli island and darang district of Assam. Indian J Trad Knowl 6(1):191-194.

Bray HG, Thorpe WV (1954) Analysis of phenolic compounds of interest in metabolism. Meth Biochem Anal 1:27-52.

Boateng J, Verghese M, Walker LT, Ogutu S (2008). Effect of processing on anti-oxidant contents in selected dry beans (Phaseolus spp. L.). Food Sci Technol 41(9):1541-1547.

Capar SG, Tanner JT, Friedman MH, Boyer KW (1978). Multielement analysis of animal feed, animal waste and sewage sludge. Environ Sci Technol 12:785.

Chitra U, Singh U, Rao PV (1996). Phytic acid, in-vitro protein digestibility, dietary fiber and minerals of pulses as influenced by processing methods. Plant Foods Hum Nutr 49(4):307-316.

Cooper HD, Spilane C, Anishetty NM, Griffee P (1996). Promoting the identification, conservation and use of wild plants for food and agriculture in the Mediterranean, The FAO Global Plan of Action, FAO, Rome.

Jimoh FO, Oladiji AT (2005). Preliminary studies on Piliostigma thonningii seeds: Proximate analysis, mineral composition and phytochemical screening.African J Biotech 4(12):1439-1442.

Kayang H (2007). Tribal knowledge on wild edible plants of Meghalaya, Northeast India. Indian. J Trad Knowl 6(1):177181.
Kingsley OM (1995). Effect of processing on some anti-nutritive and toxic components and on the nutritional composition of the African oil bean seed (Pentaclethra macrophylla Benth). J Sci Food Agric 68:153-158.

Mahadevan A, Sridhar R (1986). Methods in Physiological Plant Pathology, Sivakami Publications, Chennai, India.

Meiners CR, Derise NL, Lall HC, Crews MG, Ritchey SJ, Murphy EW (1976). The content of nine mineral elements in raw and cooked mature dry legumes. J Agric Food Chem 24:1126-1130.

Morris DL (1948). Quantitative determination of carbohydrates with drywood's anthrone reagent. Science 107:254-255.

Ologhobo AD, Fetuga BL (1988). Effects of different processes on the carbohydrates of lima bean. Nahrung 32(2):173177.

Ramachandra VS (2007). Wild edible plants of the Annamalai, Coimbatore district, Western Ghats, Tamil nadu. Indian J Trad Knowl 6(1):173-176.

Salam JS, Singh PK, Dutta BK, Sahoo UK (2009). Chemical composition and nutritive indices in Parkia roxburghii G. Don, a leguminous plant of India. Indian J Agric Biochem 22(2):87-95.

Salam JS, Singh PK, Dutta BK, Sahoo UK (2010). Effect of processing and cooking methods on some anti-nutritive, toxic components and nutritional constituents in Stink bean (Parkia roxburghii G. Don) seeds. India J Agric Biochem 23(2):97-102.

Saroj B, Neelam Kh, (1994) Saponin content and trypsin inhibitor of pea cultivars: Effect of domestic processing and cooking methods. J Food Sci Technol 31(1):73-76.

Sharma BD, Hore DK, Salam JS, (1993). Parkia roxburghii- A useful tree of North-East India. Indian J Pl Genet Resources 6(2):171-173.

Sinha R, Kawatra A (2003). Effect of processing on phytic acid and polyphenol contents of cowpeas (Vigna unguiculata (L) Walp). Plant Food Human Nutri 58(3):1-8.

Talwar GP, Srivastava LM, Mudgil KD (1989). Textbook of Biochemistry and Human Biology, (2nd ed), Prentice Hall of India Private Ltd.

Tandon HLS (1993). Methods of Analysis of Soils, Plants and fertilizers, Fertilizer Development and Consultation Organization, New Delhi.

Thimmaiah SR (2006). Standard Methods of Biochemical Analysis. Kalyani Publishers, New Delhi, India. 